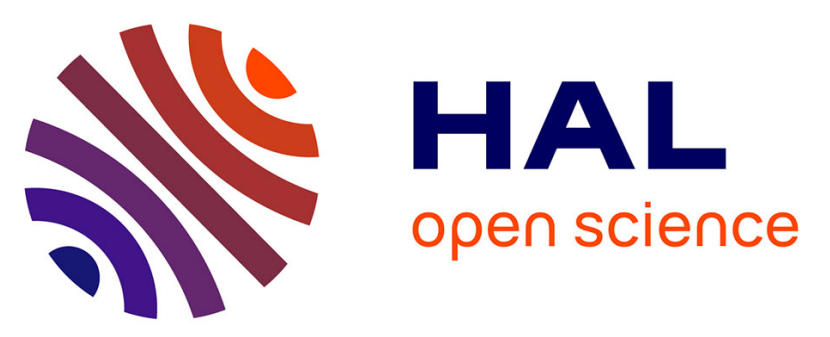

\title{
Electrophysiological Study-Guided Permanent Pacemaker Implantation In Patients With Conduction Disturbances Following Transcatheter Aortic Valve Implantation
}

\author{
Hamed Bourenane, Vincent Galand, Dominique Boulmier, Christophe \\ Leclercq, Guillaume Leurent, Marc Bedossa, Nathalie Behar, Camille Pichard, \\ Baptiste Polin, Jacques Tomasi, et al.
}

\section{- To cite this version:}

Hamed Bourenane, Vincent Galand, Dominique Boulmier, Christophe Leclercq, Guillaume Leurent, et al.. Electrophysiological Study-Guided Permanent Pacemaker Implantation In Patients With Conduction Disturbances Following Transcatheter Aortic Valve Implantation. American Journal of Cardiology, 2021, 149, pp.78-85. 10.1016/j.amjcard.2021.03.014 . hal-03191952

\section{HAL Id: hal-03191952 \\ https://hal.science/hal-03191952}

Submitted on 21 Apr 2021

HAL is a multi-disciplinary open access archive for the deposit and dissemination of scientific research documents, whether they are published or not. The documents may come from teaching and research institutions in France or abroad, or from public or private research centers.
L'archive ouverte pluridisciplinaire HAL, est destinée au dépôt et à la diffusion de documents scientifiques de niveau recherche, publiés ou non, émanant des établissements d'enseignement et de recherche français ou étrangers, des laboratoires publics ou privés. 


\section{Electrophysiological Study-Guided Permanent Pacemaker Implantation In Patients With Conduction Disturbances Following Transcatheter Aortic Valve Implantation}

Hamed Bourenane, $\mathrm{MD}^{1}$, Vincent Galand, $\mathrm{MD}^{1}$, Dominique Boulmier, $\mathrm{MD}^{1}$, Christophe Leclercq, MD, $\mathrm{PhD}^{1}$, Guillaume Leurent, $\mathrm{MD}^{1}$, Marc Bedossa, $\mathrm{MD}^{1}$, Nathalie Behar, $\mathrm{MD}^{1}$, Camille Pichard, $\mathrm{MD}^{1}$, Baptiste Polin, $\mathrm{MD}^{1}$, Jacques Tomasi, $\mathrm{MD}^{1}$, Jean-Philippe Verhoye, $\mathrm{MD}, \mathrm{PhD}^{1}$, Sam Sharobeem, $\mathrm{MSc}^{1}$, Marielle Le Guellec, $\mathrm{MSc}^{1}$, Erwan Donal, MD, $\mathrm{PhD}^{1}$, Dominique Pavin, $\mathrm{MD}^{1}$, Raphael P. Martins, MD, $\mathrm{PhD}^{1}$, Hervé Le Breton, $\mathrm{MD}^{1}$, and Vincent Auffret, $\mathrm{MD}, \mathrm{PhD}^{1}$

Authors affiliations:

1. Univ Rennes, CHU Rennes, Inserm, LTSI - UMR1099, F 35000 Rennes, France.

Short Title: EPS-guided PPM implantation post-TAVI.

Word count: 3515

Disclosures: Dr Vincent Auffret received lecture fees from Edwards Lifescience and Medtronic. Pr Hervé Le Breton received lecture fees from Edwards Lifesciences. The other authors have nothing to disclose.

Funding: No extra-mural funding supported this work

Address for correspondence:

Vincent Auffret, MD, PhD

Service de Cardiologie

CHU Pontchaillou

2 rue Henri Le Guilloux, 35000 Rennes, France.

Phone: + 33299282 505, Fax: +33299282 503

Email: vincent.auffret@chu-rennes.fr 


\section{ABSTRACT}

Conduction disturbances remain common following transcatheter aortic valve implantation (TAVI). Aside from high-degree atrioventricular block (HAVB), their optimal management remains elusive. Invasive electrophysiological studies (EPS) may help stratify patients at low or high risk of HAVB allowing for an early discharge or permanent pacemaker (PPM) implantation among patients with conduction disturbances. We evaluated the safety and diagnostic performances of an EPS-guided PPM implantation strategy among TAVI recipients with conduction disturbances not representing absolute indications for PPM. All patients who underwent TAVI at a single expert center from June 2017 to July 2020 who underwent an EPS during the index hospitalization were included in the present study. False negative outcomes were defined as patients discharged without PPM implantation who required PPM for HAVB within 6 months of the initial EPS. False positive outcomes were defined as patients discharged with a PPM with a ventricular pacing percentage $<1 \%$ at follow-up. A total of 78 patients were included (median age: 82.4 years, 38\% female), among whom 35 patients $(45 \%)$ received a PPM following EPS. The sensitivity, specificity, positive and negative predictive values of the EPS-guided PPM implantation strategy were $100 \%$, $89.6 \%, 81.5 \%$, and $100 \%$, respectively. Six patients suffered a mechanical HAVB during EPS and received a PPM. These 6 patients showed PPM dependency at follow-up. In conclusion, an EPS-guided PPM implantation strategy for managing post-TAVI conduction disturbances appears effective to identify patients who can be safely discharged without PPM implantation.

Keywords: Transcatheter aortic valve replacement; Electrophysiological study, bundle branch block, atrioventricular block, pacemaker 
A series of large prospective randomized trials established the superiority of transcatheter aortic valve implantation (TAVI) over surgical aortic valve replacement in treating patients with severe aortic stenosis with intermediate to high surgical risk ${ }^{1}$ and more recently its shortterm non-inferiority among low surgical risk patients ${ }^{2,3}$. Unlike other periprocedural complications, conduction disturbances (i.e. mainly high-degree atrioventricular block [HAVB] requiring permanent pacemaker $[\mathrm{PPM}]$ implantation and new-onset left bundlebranch block [LBBB]) have remained stable with recent reports even suggesting an increased risk associated with the newer- generation transcatheter heart valves ${ }^{4,5}$. While HAVB represents an unequivocal PPM indication in international guidelines ${ }^{6}$, the management of milder conduction disturbances such as worsening or new-onset first-degree atrioventricular block (FDAVB) or LBBB remains controversial. Experts have suggested the use of electrophysiological studies (EPS) may help stratify patients with post-TAVI new-onset or worsening conduction disturbances who would require PPM implantation ${ }^{5,7}$. However, this suggestion relies on small retrospective studies, and, considering the evolving nature of postTAVI conduction disturbances, the overall mid-term diagnostic performances of an inhospital EPS-guided PPM implantation strategy remain unclear. The objective of this study was to evaluate the safety and diagnostic performances of such a strategy.

\section{METHODS}

The full version of the methods can be find in the supplemental appendix. A retrospective study of patients who underwent TAVI at a single center was performed. Patients with post-TAVI persistent new-onset or worsening conduction disturbances not representing absolute PPM indications who underwent EPS during the index hospitalization were included in the present study. All patients gave written informed consent for the procedures and anonymous collection of their data, which were prospectively gathered in an 
electronic database as part of the FRANCE TAVI registry ${ }^{8}$. Details regarding the preprocedural workup were previously described ${ }^{9}$. Post- procedural care consisted of heart rhythm monitoring for at least 48 hours after intervention, laboratory tests and a 12-lead electrocardiogram (ECG) on a daily basis. Clinical outcomes were defined according to Valve Academic Research Consortium 2 criteria $^{10}$.

The surface ECGs before the TAVI procedure and at the time of the EPS, were employed to record rhythm, heart rate, PR interval, and QRS duration. Left anterior and posterior fascicular hemiblocks, LBBB, and right bundle branch block (RBBB) were defined according to the American Heart Association, American College of Cardiology Foundation, and Heart Rhythm Society recommendations for standardization and interpretation of the electrocardiogram ${ }^{6}$. HAVB was defined as type 2 second degree AVB or third degree AVB. Patients with persistent HAVB post-TAVI underwent PPM implantation in accordance with current European guidelines ${ }^{6}$. For patients with milder new-onset or worsening conduction disturbances persisting without improvement upon serial ECG at least $24 \mathrm{~h}$ after the procedure, a local EPS-guided PPM implantation strategy was implemented in our center in June 2017. A senior electrophysiologist performed the EPS in the local electrophysiology laboratory, and all measurements were carried out on a General Electric electrophysiology workstation. PPM implantation was recommended for an infra-hisian significant conduction delay defined as HV interval > 70ms, or second- or third-degree His-Purkinje block demonstrated during incremental atrial pacing with a rate $\leq 100 \mathrm{bpm}$. Final decision for PPM was at the discretion of the electrophysiologist taking into account the EPS findings but also the in-hospital ECG evolution and clinical data.

Follow-up was performed by on-site clinical visit and/or telephone at 1-month postTAVI, at 1 year and yearly thereafter. Records from referring cardiologists, general 
practitioners, and other hospitals were retrieved for further information. Ventricular pacing (VP) percentage was recorded among patients who underwent PPM implantation.

The primary objective of the study was to evaluate the diagnostic performances (sensitivity, specificity, positive and negative predictive value) of the local EPS-guided PPM implantation strategy. False negative outcomes were defined as patients discharged without PPM implantation who required PPM for HAVB within 6 months of the initial EPS procedure. False positive outcomes were defined as patients discharged with a PPM with a ventricular pacing (VP) percentage $<1 \%$ at follow-up. Patients who received a pacemaker due to mechanically-induced HAVB during EPS (bump of the right bundle branch in patients with an LBBB) were not included in the calculation of these diagnostic performances as they do not represent patients among whom conduction disturbances were solely TAVI-related.

Continuous variables were presented as mean \pm standard deviation or median (interquartile range) depending on their distribution, which was assessed using the Kolmogorov-Smirnov test, and were compared using t-tests or the Mann-Whitney U test as appropriate. Categorical variables were summarized as numbers (percentages), and compared using chi-square tests or the Fisher exact test. A multivariable backward stepwise logistic regression was performed to identify prolonged HV predictors. Variables with a p-value $<0.1$ in univariable analysis were included in the model. Results were reported as adjusted oddsratio (OR) with the corresponding $95 \%$ confidence interval $(\mathrm{CI})$. All tests were 2 -sided at the 0.05 significance level. Statistical analyses were conducted using the Statistical Package for Social Sciences version 25 (SPSS Inc., IBM, Armonk, New York).

\section{RESULTS}

Figure 1 provides the flow-chart of the study population. Baseline characteristics of the population are detailed in Table 1. There was no statistically significant difference 
between the PPM and no PPM groups except for a higher body mass index and a more frequent history of pulmonary edema in the former group. Table 2 summarizes ECG findings before and after TAVI. There was no significant difference in procedural characteristics and in-hospital complications between the two groups (Table 3).

Post-TAVI ECG changes leading to the performance of the EPS are detailed in Figure 2. EPS was performed at a median of 3 days (2-5) following TAVI. There was no difference in EPS indication or timing between the PPM and no PPM groups ( $p=0.62$ and 0.57 , respectively). Median HV interval was $65 \mathrm{~ms}$ (56-79) in the total population, $80 \mathrm{~ms}$ (73-92) in the PPM group, and $60 \mathrm{~ms}(50-65)$ in the no PPM group $(\mathrm{p}<0.001)$. Thirty patients had a HV interval $>70 \mathrm{~ms}$. Six mechanically induced AVB by direct injury to the right bundle branch in patients with LBBB occurred and led to PPM implantation. No other complication of the EPS occurred. Multivariable predictors of a prolonged HV interval (>70ms) were the pre-TAVI PR interval $(\mathrm{OR}=1.02,95 \% \mathrm{CI}: 1.003-1.03 ; \mathrm{p}=0.02)$, and the post-TAVI aortic valve area $(\mathrm{OR}=0.09,95 \% \mathrm{CI}: 0.02-0.49 ; \mathrm{p}=0.005)$

PPM implantation was deemed necessary by the operator and performed in 35 patients following EPS. Among them, HV interval $>70 \mathrm{~ms}$ was the sole indication for PPM for 26 patients. Mechanical HAVB during EPS led to PPM implantation in 6 patients, among whom 3 had a $\mathrm{HV}$ interval $\leq 70 \mathrm{~ms}$. In one of these patients, right bundle branch block injury precluded any $\mathrm{HV}$ interval measurement and required prompt PPM implantation. PPM implantation was decided by the operator despite HV intervals $\leq 70 \mathrm{~ms}$ in 3 cases: one for a long antegrade effective refractory period of the atrioventricular node $(700 \mathrm{~ms})$, one for a 160ms RBBB with supra-hisian AV block, and one for junctional rhythm and sinus node dysfunction associated with a $160 \mathrm{~ms}$ LBBB and a HV interval of $70 \mathrm{~ms}$. On the contrary, 2 patients with a HV interval > 70ms did not receive PPM: one with a HV interval of 78ms who 
demonstrated a complete resolution of his conduction disturbances after the EPS, and one with a borderline $\mathrm{HV}$ of $71 \mathrm{~ms}$ and a supra-hisian block with an antegrade effective refractory period of the atrioventricular node of 470ms. PPM brand were Microport CRM-Sorin in 12 patients (33\%), St-Jude Medical in 9 patients (25\%), Medtronic in 8 patients (22\%), Biotronik in 4 patients (11\%), and Boston scientific in 3 patients $(8 \%)$. Programmed modes were VVI/VVIR in 17 patients (47\%), DDD/DDDR in 13 (36\%), and DDD-ADIR, AAI-DDD, or AAI-SafeR in $6(17 \%)$. Among patients with a VVI/VVIR pacemaker, the basal pacing rate or hysteresis was $\leq 45 \mathrm{bpm}$ in $7, \leq 55 \mathrm{bpm}$ in 7 and 60/min in the remaining 3 patients.

The median follow-up was 147 (71-465) days. There was no significant difference between the two groups regarding all-cause death, heart failure hospitalizations or new-onset AF. No SCD occurred (Table 3). Among patients without PPM at discharge, one patient reported episodes of faintness, which were not associated with high-degree conduction disturbances. Two patients received a PPM. The first received CRT at a follow-up of 386 days for heart failure associated with reduced left ventricular ejection fraction and a newonset persistent LBBB of $180 \mathrm{~ms}$ (160ms at discharge), the second received CRT for faintness, type 1 second-degree AVB, LBBB and reduced left ventricular ejection fraction at a followup of 617 days. Among the PPM group, one lead fracture requiring PPM extraction without reimplantation in a patient with a VP percentage $<1 \%$ was reported. One upgrading to CRT was required 527 days after PPM implantation for heart failure and left ventricular dysfunction in a patient with a VP percentage of $90 \%$.

Figure 3 illustrates the repartition of VP percentage among PPM patients at a median follow-up of 137 days (68-406 days). VP percentage was retrieved for 33 out of 35 PPM patients $(94.3 \%)$. One patient died from a non-cardiovascular cause before the first device assessment. For the second patient, we were unable to obtain data regarding VP percentage 
despite completing the clinical follow-up. After exclusion of the 6 patients implanted for a mechanically-induced AVB, the diagnostic performances of the EPS-guided PPM implantation strategy were evaluated among 27 PPM recipients and 43 of their no-PPM counterparts. The rate of false negative outcomes was $0 \%$. False positive outcomes occurred in $5(18.5 \%)$ patients without differences between patients with a VVI/VVIR pacemaker and patients with other modes ( 3 vs. 2 patients, $\mathrm{p}=0.20$ ). The underlying rhythm pathologies requiring pacing in these subjects are summarized in supplemental table 1. The sensitivity, specificity, positive and negative predictive values of the EPS-guided PPM implantation strategy were $100 \%, 89.6 \%, 81.5 \%$, and $100 \%$, respectively. Of note, among the 6 PPM patients with a mechanical AVB, 3 had a VP percentage between 1 and $25 \%$ while 3 had a VP percentage $>50 \%$.

\section{DISCUSSION}

The natural history of post-TAVI conduction disturbances and their most appropriate management remain unclear due to the scarcity of prospective studies addressing this issue. The multicenter prospective LBBB-TAVI study focusing on post-TAVI new-onset LBBB will hopefully shed some light on this area $^{11}$. The Ambulatory Electrocardiographic Monitoring for the Detection of High-Degree Atrio-Ventricular Block in Patients With Newonset PeRsistent LEft Bundle Branch Block After Transcatheter Aortic Valve Implantation (MARE) study elegantly provided insights into the natural history of TAVI-induced newonset LBBB by implanting a cardiac monitor in 103 TAVI recipients ${ }^{12}$. PPM implantation was required for HAVB or severe bradycardia in $10 \%$ of these patients at a mean delay of 42 days following TAVI. Therefore, allowing such patients to be discharged without PPM implantation based solely on routine ECG and continuous rhythm monitoring data may subject a significant proportion of them to the risk of a life-threatening bradyarrhythmia. On 
the other hand, a recent meta-analysis suggested an increased risk of long-term mortality and heart failure hospitalization associated with PPM implantation post-TAVI ${ }^{4}$.

EPS appears as a potential candidate to help select patients who will benefit from PPM implantation or conversely who can be safely discharged without PPM implantation. An expert panel recently suggested that EPS may play a significant role in selecting PPM implantation candidates in two specific groups of patients: patients with ECG changes (increase in $\mathrm{PR}$ or $\mathrm{QRS}$ duration $\geq 20 \mathrm{~ms}$ ) in the presence of pre-TAVI conduction disturbances, and patients with new-onset $\mathrm{LBBB}^{7}$.

To date, studies assessing the role of EPS in the post-TAVI setting have been scarce and each included less than 100 patients $^{13}$. In four studies assessing the value of a post-TAVI EPS in predicting PPM implantation, with a HV interval cut-off ranging from 65 to $100 \mathrm{~ms}$, and reported a long-term follow-up and the need for PPM, no SCD occurred and no patients needed a PPM during at least 1 year of follow-up ${ }^{13}$. Only two prior studies, including 121 patients undergoing EPS, truly reported the results of predefined EPS-guided strategies ${ }^{13}$. Tovia-Brodie et al. presented the results of 81 patients with conduction abnormalities after TAVI, showing an improved event-free survival (mortality or PPM implantation) among the 26 EPS-assessed patients with a 75ms HV interval cut-off prompting PPM implantation (9\% vs. $0 \%, p=0.04)^{14}$. In another study including 95 patients who developed conduction disturbances without an absolute indication for PPM, Rogers et al. showed the safety of their EPS-guided strategy regarding the risk of PPM implantation without significant mortality difference at 1-year of follow-up between patients who received a PPM and those who did not based on the EPS findings ${ }^{15}$. However, the $\mathrm{HV}$ interval threshold prompting PPM implantation was $100 \mathrm{~ms}$ with a pharmacological test involving IV procainamide, which is not available worldwide, limiting the reproducibility of the study. In addition to this two previous 
studies, the present analysis provides valuable data regarding the mid-term diagnostic performances of an EPS-guided strategy by evaluating the ability of a post-TAVI EPS to predict PPM dependency at follow-up. We demonstrated an acceptable $18.5 \%$ rate of false positive patients, with VP percentage $<1 \%$ at follow-up, using a single, widely accepted, 70ms HV interval cut-off.

A theoretical limitation of the use of EPS in the post-TAVI conduction disturbances setting is the "screenshot" characteristic of EPS, which captures AV conduction properties at a specific time. Indeed, it is well described that post-TAVI conduction disturbances may worsen or improve over time ${ }^{5}$. Therefore, the prognostic value of an EPS performed during the index hospitalization regarding the prediction of late HAVB or PPM dependency remains largely elusive. To circumvent this limitation, experts recommend that EPS is realized at least $24 \mathrm{~h}$ after TAVI and after stabilization of ECG findings. Using a strategy essentially aligned with this recommendation, with a $\mathrm{HV}$ interval cut-off of 70ms prompting PPM implantation, which falls in the range proposed by Tovia-Brodie et $\mathrm{al}^{13}$, we demonstrated a reassuring $100 \%$ NPV regarding PPM requirement within the first 6 months of follow-up among patients with a negative EPS.

Importantly, the EPS-guided PPM implantation strategy was associated with a significant number of HAVB induced by a direct injury to the right bundle branch as $7.6 \%$ of patients were implanted because of a mechanical HAVB. None of these patients were considered PPM independent at follow-up. Nonetheless, this observation stresses the need to reduce EPS-related implantation to further increase the safety of EPS-guided PPM implantation strategies.

In the three EPS-guided PPM implantation studies, which assessed PPM dependency post-TAVI, one used a dependency definition of VP $>50 \%$ while the others defined PPM 
dependency as underlying permanent $\mathrm{AV}$ block $^{16-18}$. In the present study, we aimed at "penalizing" the negative predictive value estimation to increase the confidence regarding the long-term safety of our strategy. Therefore, we chose a conservative definition of VP>1\% for PM dependency, since even rare paroxysmal HAVB, which would translate in a low VP percentage, may cause SCD or serious bradyarrhythmia-related events.

Several limitations of the present analysis should be considered. First, this was a single-center study of limited size, which may limit the generalizability of our results. Second, most patients received a balloon-expandable valve, the magnitude and timing of effect of which upon the conduction system may differ from other transcatheter heart valve designs. However, in a recent study including 2804 patients, $82 \%$ and $94 \%$ of conduction disturbances occurred within $48 \mathrm{~h}$ and 4 days of TAVI, respectively, without difference between valve type $^{19}$. The MARE study demonstrated no difference in the timing of bradyarrhythmic events post-TAVI according to valve type, and self-expandable valves were not a significant predictor of delayed HAVB in a study by Toggweiler et al. including 1064 TAVI recipients ${ }^{20}$. On the contrary, a small study encompassing 133 patients demonstrated a delayed occurrence of PR prolongation among self-expandable valve recipients compared with their balloonexpandable counterparts ${ }^{21}$. However, PR prolongation occurred within $48 \mathrm{~h}$ of the procedure after self-expandable valves' implantation. Thus, it is unlikely that the indications and diagnostic performances of our strategy would be vastly different in a population including a greater proportion of self-expandable valves given the 3 days median delay between TAVI and EPS in the present study. Finally, the choice of pacemaker brand, programmed modes and frequencies were not protocoled but left to the operator discretion. Thus, although programs preserving spontaneous conduction were systematically preferred, the interpretation of pacing data from device interrogations may be challenging. 


\section{CRediT Author statement}

Hamed Bourenane : Data curation, Writing original draft, review. Vincent Galand : Data curation, review. Dominique Boulmier : Data curation, review. Christophe Leclercq : Data curation, review Guillaume Leurent : Data curation, review. Marc Bedossa : Data curation, review. Nathalie Behar : Data curation, review. Camille Pichard : Data curation, review. Baptiste Polin : Data curation, review. Jacques Tomasi : Data curation, review. Jean-Philippe Verhoye : Data curation, review. Sam Sharobeem : Data curation. Marielle Le Guellec : Data curation. Erwan Donal : Data curation, review. Dominique Pavin : Data curation, review. Raphael P. Martins : Data curation, review. Hervé Le Breton : Data curation, review, validation and Vincent Auffret : Conceptualization, Data curation, Formal analysis, supervision, writing original draft, review, editing, validation.

\section{Declaration of interests}

$\square$ The authors declare that they have no known competing financial interests or personal relationships that could have appeared to influence the work reported in this paper.

$\bigotimes$ The authors declare the following financial interests/personal relationships which may be considered as potential competing interests:

Dr Vincent Auffret received lecture fees from Edwards Lifescience and Medtronic. Pr Hervé Le Breton received lecture fees from Edwards Lifesciences. The other authors have nothing to disclose.

References 
1. Siontis GCM, Praz F, Pilgrim T, Mavridis D, Verma S, Salanti G, Søndergaard L, Jüni P, Windecker S. Transcatheter aortic valve implantation vs. surgical aortic valve replacement for treatment of severe aortic stenosis: a meta-analysis of randomized trials. Eur Heart $J$ 2016;37:3503-3512.

2. Mack MJ, Leon MB, Thourani VH, Makkar R, Kodali SK, Russo M, Kapadia SR, Malaisrie SC, Cohen DJ, Pibarot P, Leipsic J, Hahn RT, Blanke P, Williams MR, McCabe JM, Brown DL, Babaliaros V, Goldman S, Szeto WY, Genereux P, Pershad A, Pocock SJ, Alu MC, Webb JG, Smith CR. Transcatheter Aortic-Valve Replacement with a BalloonExpandable Valve in Low-Risk Patients. N Engl J Med 2019;380:1695-1705.

3. Popma JJ, Deeb GM, Yakubov SJ, Mumtaz M, Gada H, O’Hair D, Bajwa T, Heiser JC, Merhi W, Kleiman NS, Askew J, Sorajja P, Rovin J, Chetcuti SJ, Adams DH, Teirstein PS, Zorn GL 3rd, Forrest JK, Tchetche D, Resar J, Walton A, Piazza N, Ramlawi B, Robinson N, Petrossian G, Gleason TG, Oh JK, Boulware MJ, Qiao H, Mugglin AS, Reardon MJ. Transcatheter Aortic-Valve Replacement with a Self-Expanding Valve in Low-Risk Patients. N Engl J Med 2019;380:1706-1715.

4. Faroux L, Chen S, Muntané-Carol G, Regueiro A, Philippon F, Sondergaard L, Jørgensen TH, Lopez-Aguilera J, Kodali S, Leon M, Nazif T, Rodés-Cabau J. Clinical impact of conduction disturbances in transcatheter aortic valve replacement recipients: a systematic review and meta-analysis. Eur Heart J 2020;41:2771-2781.

5. Auffret Vincent, Puri Rishi, Urena Marina, Chamandi Chekrallah, Rodriguez-Gabella Tania, Philippon François, Rodés-Cabau Josep. Conduction Disturbances After Transcatheter Aortic Valve Replacement. Circulation 2017;136:1049-1069. 
6. Brignole M, Auricchio A, Baron-Esquivias G, Bordachar P, Boriani G, Breithardt OA, Cleland J, Deharo JC, Delgado V, Elliott PM, Gorenek B, Israel CW, Leclercq C, Linde C, Mont L, Padeletti L, Sutton R, Vardas PE, Zamorano JL, Achenbach S, Baumgartner H, Bax JJ, Bueno H, Dean V, Deaton C, Erol C, Fagard R, Ferrari R, Hasdai D, Hoes AW, Kirchhof P, Knuuti J, Kolh P, Lancellotti P, Linhart A, Nihoyannopoulos P, Piepoli MF, Ponikowski P, Sirnes PA, Tamargo JL, Tendera M, Torbicki A, Wijns W, Windecker S, Kirchhof P, Blomstrom-Lundqvist C, Badano LP, Aliyev F, Bansch D, Baumgartner H, et al. 2013 ESC Guidelines on cardiac pacing and cardiac resynchronization therapy: the Task Force on cardiac pacing and resynchronization therapy of the European Society of Cardiology (ESC). Developed in collaboration with the European Heart Rhythm Association (EHRA). Eur Heart $J$ 2013;34:2281-329.

7. Rodés-Cabau J, Ellenbogen KA, Krahn AD, Latib A, Mack M, Mittal S, Muntané-Carol G, Nazif TM, Sondergaard L, Urena M, Windecker S, Philippon F. Management of Conduction Disturbances Associated With Transcatheter Aortic Valve Replacement: JACC Scientific Expert Panel. J Am Coll Cardiol 2019;74:1086-1106.

8. Auffret V, Lefevre T, Van Belle E, Eltchaninoff H, Iung B, Koning R, Motreff P, Leprince P, Verhoye JP, Manigold T, Souteyrand G, Boulmier D, Joly P, Pinaud F, Himbert D, Collet JP, Rioufol G, Ghostine S, Bar O, Dibie A, Champagnac D, Leroux L, Collet F, Teiger E, Darremont O, Folliguet T, Leclercq F, Lhermusier T, Olhmann P, Huret B, Lorgis L, Drogoul L, Bertrand B, Spaulding C, Quilliet L, Cuisset T, Delomez M, Beygui F, Claudel JP, Hepp A, Jegou A, Gommeaux A, Mirode A, Christiaens L, Christophe C, Cassat C, Metz D, Mangin L, Isaaz K, Jacquemin L, et al. Temporal Trends in Transcatheter Aortic Valve Replacement in France: FRANCE 2 to FRANCE TAVI. J Am Coll Cardiol 2017;70:42-55. 
9. Auffret V, Boulmier D, Oger E, Bedossa M, Donal E, Laurent M, Sost G, Beneux X, Harmouche M, Verhoye JP, Le Breton H. Predictors of 6-month poor clinical outcomes after transcatheter aortic valve implantation. Arch Cardiovasc Dis 2014;107:10-20.

10. Kappetein AP, Head SJ, Genereux P, Piazza N, Mieghem NM van, Blackstone EH, Brott TG, Cohen DJ, Cutlip DE, Es GA van, Hahn RT, Kirtane AJ, Krucoff MW, Kodali S, Mack MJ, Mehran R, Rodes-Cabau J, Vranckx P, Webb JG, Windecker S, Serruys PW, Leon MB. Updated standardized endpoint definitions for transcatheter aortic valve implantation: the Valve Academic Research Consortium-2 consensus document. Eur Heart J 2012;33:2403-18.

11. Massoullié G, Bordachar P, Irles D, Caussin C, Da Costa A, Defaye P, Jean F, Mechulan A, Mondoly P, Souteyrand G, Pereira B, Ploux S, Eschalier R. Prognosis assessment of persistent left bundle branch block after TAVI by an electrophysiological and remote monitoring risk-adapted algorithm: rationale and design of the multicentre LBBB-TAVI Study. BMJ Open 2016;6:e10485.

12. Rodés-Cabau J, Urena M, Nombela-Franco L, Amat-Santos I, Kleiman N, Munoz-Garcia A, Atienza F, Serra V, Deyell MW, Veiga-Fernandez G, Masson J-B, Canadas-Godoy V, Himbert D, Castrodeza J, Elizaga J, Francisco Pascual J, Webb JG, Torre JM de la, Asmarats L, Pelletier-Beaumont E, Philippon F. Arrhythmic Burden as Determined by Ambulatory Continuous Cardiac Monitoring in Patients With New-Onset Persistent Left Bundle Branch Block Following Transcatheter Aortic Valve Replacement: The MARE Study. JACC Cardiovasc Interv 2018;11:1495-1505.

13. Tovia-Brodie O, Michowitz Y, Belhassen B. Use of Electrophysiological Studies in Transcatheter Aortic Valve Implantation. Arrhythm Electrophysiol Rev 2020;9:20-27. 
14. Tovia-Brodie O, Ben-Haim Y, Joffe E, Finkelstein A, Glick A, Rosso R, Belhassen B, Michowitz Y. The value of electrophysiologic study in decision-making regarding the need for pacemaker implantation after TAVI. J Interv Card Electrophysiol 2017;48:121-130.

15. Rogers T, Devraj M, Thomaides A, Steinvil A, Lipinski MJ, Buchanan KD, Alraies MC, Koifman E, Gai J, Torguson R, Okubagzi P, Ben-Dor I, Pichard AD, Satler LF, Waksman R. Utility of Invasive Electrophysiology Studies in Patients With Severe Aortic Stenosis Undergoing Transcatheter Aortic Valve Implantation. Am J Cardiol 2018;121:1351-1357.

16. Makki N, Dollery J, Jones D, Crestanello J, Lilly S. Conduction disturbances after TAVR: Electrophysiological studies and pacemaker dependency. Cardiovasc Revasc Med 2017;18:S10-S13.

17. Badenco N, Chong-Nguyen C, Maupain C, Himbert C, Duthoit G, Waintraub X, Chastre T, Gandjbakhch E, Hidden-Lucet F, Le Prince P, Collet JP, Frank R. Respective role of surface electrocardiogram and His bundle recordings to assess the risk of atrioventricular block after transcatheter aortic valve replacement. Int J Cardiol 2017;236:216-220.

18. Kostopoulou A, Karyofillis P, Livanis E, Thomopoulou S, Stefopoulos C, Doudoumis K, Theodorakis G, Voudris V. Permanent pacing after transcatheter aortic valve implantation of a CoreValve prosthesis as determined by electrocardiographic and electrophysiological predictors: a single-centre experience. Europace 2016;18:131-137.

19. Kooistra NHM, Mourik MS van, Rodríguez-Olivares R, Maass AH, Nijenhuis VJ, Werf R van der, Ten Berg JM, Kraaijeveld AO, Baan J, Voskuil M, Vis MM, Stella PR. Late onset of new conduction disturbances requiring permanent pacemaker implantation following TAVI. Heart 2020;106:1244-1251. 
20. Toggweiler S, Stortecky S, Holy E, Zuk K, Cuculi F, Nietlispach F, Sabti Z, Suciu R, Maier W, Jamshidi P, Maisano F, Windecker S, Kobza R, Wenaweser P, Lüscher TF, Binder RK. The Electrocardiogram After Transcatheter Aortic Valve Replacement Determines the Risk for Post-Procedural High-Degree AV Block and the Need for Telemetry Monitoring. JACC Cardiovasc Interv 2016;9:1269-1276.

21. Coeman M, Kayaert P, Philipsen T, Calle S, Gheeraert P, Gevaert S, Czapla J, Timmers

L, Van Heuverswyn F, De Pooter J. Different dynamics of new-onset electrocardiographic changes after balloon- and self-expandable transcatheter aortic valve replacement: Implications for prolonged heart rhythm monitoring. J Electrocardiol 2020;59:68-73.

\section{FIGURES LEGENDS}

\section{Figure 1- Flow chart of the study population}

EPS: electrophysiological study; ESC: European Society of Cardiology; PPM: permanent pacemaker; TAVI: transcatheter aortic valve implantation.

\section{Figure 2 -Indications for the electrophysiological study}

Data are presented as n (\%). CAVB: complete atrioventricular block; FDAVB: first degree atrioventricular block; LBBB: left bundle branch block; LFAHB: left fascicular anterior hemi block; RBBB: right bundle branch block.

* FDAVB and LFAHB were new-onset whereas RBBB was pre-existing in both patients

\section{Figure 3 - Ventricular pacing percentage at follow-up}

Data are presented as $\mathrm{n}(\%)$ in each category. VP: ventricular pacing 

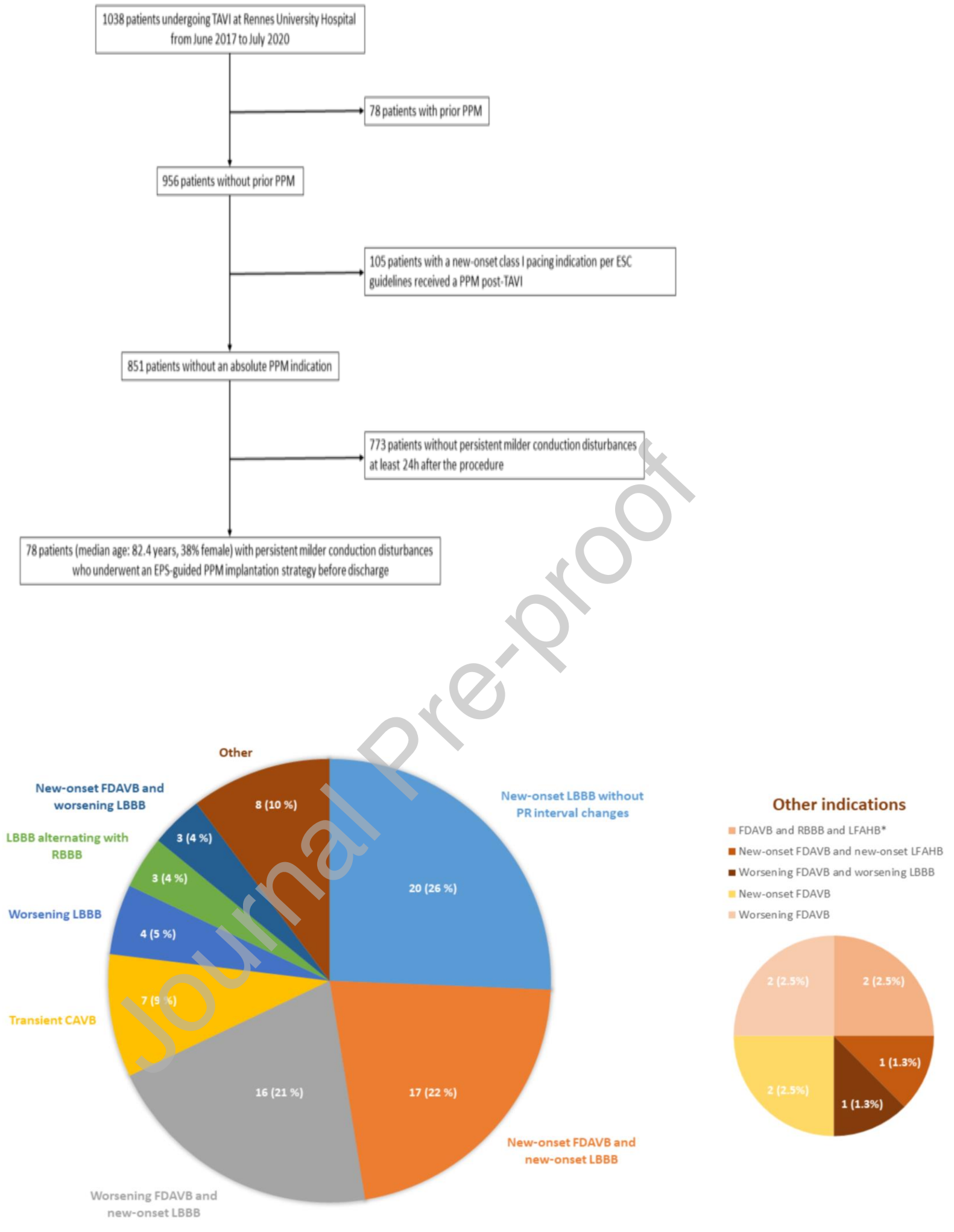


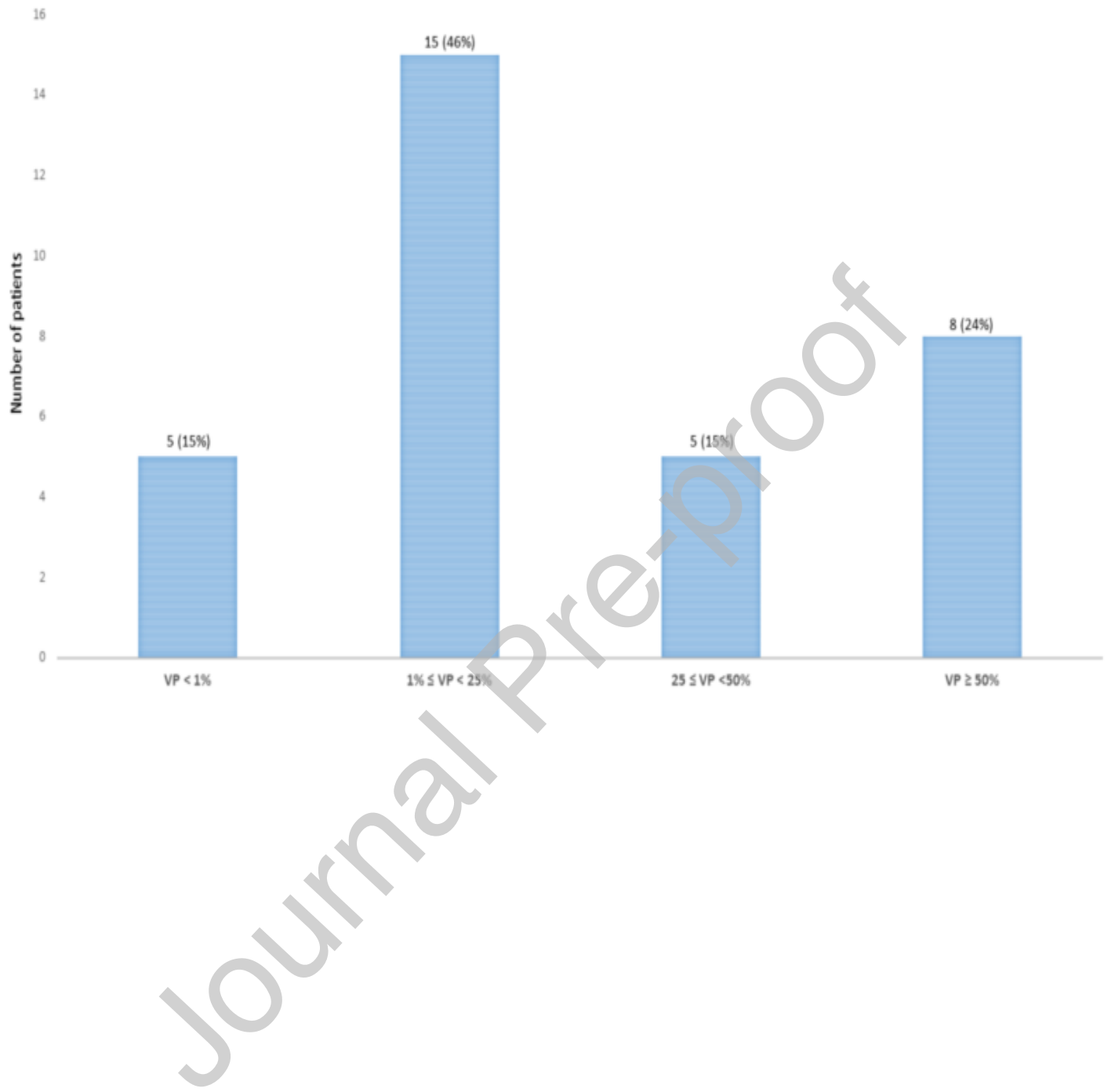


Table 1 : Baseline characteristics according to in-hospital permanent pacemaker implantation

\begin{tabular}{|c|c|c|c|c|}
\hline Variable & $\begin{array}{l}\text { All patients } \\
\qquad(n=78)\end{array}$ & $\begin{array}{c}\text { PPM } \\
(n=35)\end{array}$ & $\begin{array}{c}\text { No PPM } \\
(n=43)\end{array}$ & p value \\
\hline Age (years) & $83.5(80.0-86.3)$ & $84.0(79.0-87.0)$ & $83.0(80.0-86.0)$ & 0.84 \\
\hline Women & $30(39 \%)$ & $12(34 \%)$ & $18(42 \%)$ & 0.64 \\
\hline Body-mass index $\left(\mathrm{kg} / \mathrm{m}^{2}\right)$ & $25.9(23.3-29.1)$ & $28.0(24.8-29.4)$ & $25.1(22.3-28.4)$ & 0.03 \\
\hline Prior myocardial infarction & $1(1 \%)$ & $1(3 \%)$ & $0(0 \%)$ & 0.45 \\
\hline Prior CABG & $4(5 \%)$ & $2(6 \%)$ & $2(5 \%)$ & 1.00 \\
\hline Prior PCI & $16(21 \%)$ & $8(23 \%)$ & $8(19 \%)$ & 0.78 \\
\hline Prior stroke or TIA & $9(12 \%)$ & $3(9 \%)$ & $6(14 \%)$ & 0.50 \\
\hline Peripheral vascular disease & $19(24 \%)$ & $10(29 \%)$ & $9(21 \%)$ & 0.60 \\
\hline History of atrial fibrillation & $27(35 \%)$ & $15(43 \%)$ & $12(28 \%)$ & 0.23 \\
\hline Diabetes mellitus & $15(19 \%)$ & $8(23 \%)$ & $7(16 \%)$ & 0.57 \\
\hline Hypertension & $49(63 \%)$ & $23(66 \%)$ & $26(61 \%)$ & 0.65 \\
\hline NYHA class III or IV & $32(41 \%)$ & $16(46 \%)$ & $16(37 \%)$ & 0.49 \\
\hline Prior pulmonary oedema & $20(26 \%)$ & $13(37 \%)$ & $7(16 \%)$ & 0.04 \\
\hline Prior syncope & $6(8 \%)$ & $3(9 \%)$ & $3(7 \%)$ & 1.00 \\
\hline $\mathrm{eGFR}<60 \mathrm{ml} / \mathrm{min} / \mathrm{m}^{2}$ & $30(40 \%)$ & $16(49 \%)$ & $14(33 \%)$ & 0.24 \\
\hline Logistic EuroScore I & $10.0(7.0-17.3)$ & $14.0(6.2-22.0)$ & $9.0(7.0-15.0)$ & 0.17 \\
\hline Logistic EuroScore II & $2.1(1.5-3.3)$ & $2.7(1.7-4.8)$ & $1.9(1.4-3.1)$ & 0.11 \\
\hline \multicolumn{5}{|l|}{$\begin{array}{l}\text { Treatment at the time of } \\
\text { procedure }\end{array}$} \\
\hline Amiodarone & $10(13 \%)$ & $6(17 \%)$ & $4(9 \%)$ & 0.33 \\
\hline Calcium channel blocker & $7(9 \%)$ & $3(9 \%)$ & $4(9 \%)$ & 1.00 \\
\hline Beta blockers & $35(45 \%)$ & $13(37 \%)$ & $22(51 \%)$ & 0.26 \\
\hline Coronary artery disease & $36(46 \%)$ & $14(40 \%)$ & $22(51 \%)$ & 0.37 \\
\hline $\begin{array}{l}\text { Number of narrowed coronary } \\
\text { arteries }\end{array}$ & & & & 0.29 \\
\hline 1 & & $10(29 \%)$ & $11(26 \%)$ & \\
\hline 2 & $11(14 \%)$ & $2(6 \%)$ & $9(21 \%)$ & \\
\hline 3 & $4(5 \%)$ & $2(6 \%)$ & $2(5 \%)$ & \\
\hline \multicolumn{5}{|l|}{ Pre-TAVI Echocardiography } \\
\hline $\operatorname{LVEF}(\%)$ & $60.0(55.0-67.0)$ & $60.0(48.0-68.0)$ & $60.0(57.3-67.0)$ & 0.55 \\
\hline Aortic valve area $\left(\mathrm{cm}^{2}\right)$ & $0.73(0.62-0.81)$ & $0.75(0.62-0.83)$ & $0.71(0.61-0.80)$ & 0.77 \\
\hline Mean gradient $(\mathrm{mmHg})$ & $50.6(42.0-61.9)$ & $51.0(42.0-66.0)$ & $50.3(42.0-61.0)$ & 0.98 \\
\hline \multicolumn{5}{|l|}{ Computed tomography } \\
\hline $\begin{array}{l}\text { Perimeter-derived annulus } \\
\text { diameter }(\mathrm{mm})\end{array}$ & $25.0(22.8-26.5)$ & $25.1(23.0-26.1)$ & $24.3(22.8-26.7)$ & 0.98 \\
\hline
\end{tabular}

Values are median (interquartile range) and number $(\%) . \mathrm{CABG}=$ coronary artery bypass graft $; \mathrm{eGFR}=$ glomerular filtration rate; NYHA $=$ New York Heart Association $; \mathrm{PCI}=$ percutaneous coronary intervention $; \mathrm{LVEF}=$ left ventricular ejection fraction ;PPM = Permanent pacemaker $;$ TAVI $=$ Transcatheter aortic valve replacement $;$ TIA $=$ transient ischaemic attack 
Table 2 : ECG intervals before and following TAVI

\begin{tabular}{|c|c|c|c|c|c|c|c|c|c|c|c|c|}
\hline & $\begin{array}{l}\text { ECG pre- } \\
\text { TAVI }\end{array}$ & & & & $\begin{array}{l}\text { ECG } \\
\text { post- } \\
\text { TAVI }\end{array}$ & & & & $\begin{array}{l}\text { Difference } \\
\text { between } \\
\text { pre and } \\
\text { post } \\
\text { TAVI }\end{array}$ & & & \\
\hline & $\begin{array}{l}\text { All patients } \\
(\mathrm{N}=78)\end{array}$ & $\begin{array}{l}\text { PPM }(N \\
=35)\end{array}$ & $\begin{array}{l}\text { No } \\
\text { PPM } \\
(\mathrm{N}= \\
43)\end{array}$ & $\begin{array}{l}\mathrm{p} \\
\text { value }\end{array}$ & $\begin{array}{l}\text { All } \\
\text { patients } \\
(\mathrm{N}=78)\end{array}$ & $\begin{array}{l}\text { PPM } \\
(\mathrm{N} \\
=35)\end{array}$ & $\begin{array}{l}\text { No } \\
\text { PPM } \\
(\mathrm{N}= \\
43)\end{array}$ & $\begin{array}{l}\mathrm{p} \\
\text { value }\end{array}$ & $\begin{array}{l}\text { All } \\
\text { patients } \\
(\mathrm{N}=78)\end{array}$ & $\begin{array}{l}\text { PPM } \\
(\mathrm{N}=35)\end{array}$ & $\begin{array}{l}\text { No } \\
\text { PPM } \\
(\mathrm{N}= \\
43)\end{array}$ & $\begin{array}{l}\mathrm{p} \\
\text { value }\end{array}$ \\
\hline $\mathbf{A F}$ & $11(14 \%)$ & $4(11 \%)$ & $\begin{array}{l}7 \\
(17 \%)\end{array}$ & 0.75 & $\begin{array}{l}12 \\
(16 \%)\end{array}$ & $\begin{array}{l}5 \\
(14 \%) \\
\end{array}$ & $\begin{array}{l}7 \\
(17 \%)\end{array}$ & 1.00 & - & - & - & - \\
\hline $\begin{array}{l}\text { Heart rate } \\
(\text { bpm) }\end{array}$ & $68(61-77)$ & $\begin{array}{l}72(59- \\
76)\end{array}$ & $\begin{array}{l}68 \\
(61- \\
78) \\
\end{array}$ & 0.72 & $\begin{array}{l}71(63- \\
82)\end{array}$ & $\begin{array}{l}70 \\
(62- \\
81) \\
\end{array}$ & $\begin{array}{l}71 \\
(63- \\
82) \\
\end{array}$ & 0.41 & $3(-5-10)$ & $\begin{array}{l}1(-8- \\
9)\end{array}$ & $\begin{array}{l}5(-3 \\
-11)\end{array}$ & 0.26 \\
\hline $\begin{array}{l}\text { PR length } \\
(\mathrm{ms})\end{array}$ & $\begin{array}{l}197(178- \\
230)\end{array}$ & $\begin{array}{l}211(184- \\
242)\end{array}$ & $\begin{array}{l}192 \\
(169- \\
214) \\
\end{array}$ & 0.06 & $\begin{array}{l}236 \\
(200- \\
258) \\
\end{array}$ & $\begin{array}{l}233 \\
(200- \\
272) \\
\end{array}$ & $\begin{array}{l}236 \\
(199- \\
250) \\
\end{array}$ & 0.50 & $29(4-48)$ & $\begin{array}{l}23(8- \\
47)\end{array}$ & $\begin{array}{l}32 \\
(3- \\
54) \\
\end{array}$ & 0.80 \\
\hline FDAVB & $30(46 \%)$ & $18(58 \%)$ & $\begin{array}{l}12 \\
(34 \%)\end{array}$ & 0.08 & $\begin{array}{l}47 \\
(73 \%)\end{array}$ & $\begin{array}{l}21 \\
(72 \%)\end{array}$ & $\begin{array}{l}26 \\
(74 \%)\end{array}$ & 1.00 & & & & \\
\hline $\begin{array}{l}\text { QRS } \\
\text { duration } \\
(\mathrm{ms})\end{array}$ & $\begin{array}{l}100(90- \\
117)\end{array}$ & $\begin{array}{l}99(90- \\
119)\end{array}$ & $\begin{array}{l}101 \\
(91- \\
115) \\
\end{array}$ & 0.85 & $\begin{array}{l}155 \\
(139- \\
165) \\
\end{array}$ & $\begin{array}{l}157 \\
(142- \\
167) \\
\end{array}$ & $\begin{array}{l}152 \\
(136- \\
161) \\
\end{array}$ & 0.61 & $51(28-67)$ & $\begin{array}{l}54(35- \\
67)\end{array}$ & $\begin{array}{l}49 \\
(19- \\
65) \\
\end{array}$ & 0.61 \\
\hline QRS type & & & & 0.75 & & & & 0.89 & - & - & - & - \\
\hline $\begin{array}{l}\text { Narrow } \\
\text { QRS < } \\
100 \mathrm{~ms} \\
\end{array}$ & $48(62 \%)$ & $24(66 \%)$ & $\begin{array}{l}25 \\
(60 \%)\end{array}$ & & $2(3 \%)$ & $\begin{array}{l}1 \\
(3 \%)\end{array}$ & 1 & & & & & \\
\hline LBBB & $9(12 \%)$ & $3(9 \%)$ & $\begin{array}{l}6 \\
(14 \%) \\
\end{array}$ & & $\begin{array}{l}64 \\
(83 \%) \\
\end{array}$ & $\begin{array}{l}29 \\
(83 \%)\end{array}$ & $\begin{array}{l}35 \\
(83 \%) \\
\end{array}$ & & & & & \\
\hline RBBB & $5(7 \%)$ & $2(6 \%)$ & $\begin{array}{l}3 \\
(7 \%)\end{array}$ & & $6(8 \%)$ & $\begin{array}{l}2 \\
(6 \%)\end{array}$ & $\begin{array}{l}4 \\
(10 \%)\end{array}$ & & & & & \\
\hline UICD & $1(1 \%)$ & $1(3 \%)$ & $\begin{array}{l}0 \\
(0 \%)\end{array}$ & & $1(1 \%)$ & $\begin{array}{l}1 \\
(3 \%)\end{array}$ & $\begin{array}{l}0 \\
(0 \%)\end{array}$ & & & & & \\
\hline $\begin{array}{l}\text { Incomplete } \\
\text { LBBB }\end{array}$ & $13(17 \%)$ & $5(14 \%)$ & $\begin{array}{l}8 \\
(19 \%)\end{array}$ & & $4(5 \%)$ & $\begin{array}{l}2 \\
(6 \%)\end{array}$ & $\begin{array}{l}2 \\
(5 \%)\end{array}$ & & & & & \\
\hline $\begin{array}{l}\text { Incomplete } \\
\text { RBBB }\end{array}$ & $1(1 \%)$ & $1(3 \%)$ & $\begin{array}{l}0 \\
(0 \%) \\
\end{array}$ & & $0(0 \%)$ & $\begin{array}{l}0 \\
(0 \%) \\
\end{array}$ & $\begin{array}{l}0 \\
(0 \%) \\
\end{array}$ & & & & & \\
\hline
\end{tabular}

Values are median (interquartile range) or $\mathrm{n}(\%)$

$\mathrm{AF}=$ atrial fibrillation $; \mathrm{LBBB}=$ left bundle branch block $; \mathrm{PPM}=$ Permanent pacemaker ; $\mathrm{RBBB}=$ right bundle branch block ; UICD = unspecified intraventricular conduction disturbance TAVI = Transcatheter aortic valve replacement 
Table 3: Procedural, in-hospital and follow-up characteristics

\begin{tabular}{|c|c|c|c|c|}
\hline Variable & $\begin{array}{c}\text { All patients } \\
(\mathrm{N}=78)\end{array}$ & $\begin{array}{c}\text { PPM } \\
(\mathbf{N}=35)\end{array}$ & $\begin{array}{l}\text { No PPM } \\
(\mathrm{N}=43) \\
\end{array}$ & p value \\
\hline \multicolumn{5}{|l|}{ Procedural characteristics } \\
\hline Valve type & & & & 0.09 \\
\hline Balloon-expandable & $62(80 \%)$ & $31(89 \%)$ & $31(72 \%)$ & \\
\hline Self-expandable & $16(21 \%)$ & $4(11 \%)$ & $12(28 \%)$ & \\
\hline Femoral approach & $72(92 \%)$ & $33(94 \%)$ & $39(91 \%)$ & 0.26 \\
\hline Prosthesis size (mm) & & & & 0.88 \\
\hline 23 & $19(24 \%)$ & $9(26 \%)$ & $10(23 \%)$ & \\
\hline 26 & $32(41 \%)$ & $15(43 \%)$ & $17(40 \%)$ & \\
\hline 29 & $27(35 \%)$ & $12(31 \%)$ & $16(37 \%)$ & \\
\hline Procedural transient CAVB & $10(13 \%)$ & $7(20 \%)$ & $3(7 \%)$ & 0.10 \\
\hline \multicolumn{5}{|l|}{ In-hospital outcomes } \\
\hline Stroke & $3(4 \%)$ & $3(9 \%)$ & $0(0 \%)$ & 0.09 \\
\hline New onset AF & $3(4 \%)$ & $2(6 \%)$ & $1(2 \%)$ & 0.59 \\
\hline Vascular complication $\dagger$ & $4(5 \%)$ & $1(3 \%)$ & $3(7 \%)$ & 0.62 \\
\hline Major bleeding & $4(5 \%)$ & $2(6 \%)$ & $2(5 \%)$ & 1.00 \\
\hline \multicolumn{5}{|l|}{ Post-TAVI echocardiography } \\
\hline LVEF (\%) & $60.0(51.0-65.0)$ & $62.0(51.0-67.0)$ & $60.0(50.0-65.0)$ & 0.84 \\
\hline Aortic valve area $\left(\mathrm{cm}^{2}\right)$ & $1.81(1.54-2.11)$ & $1.70(1.40-1.95)$ & $1.92(1.60-2.30)$ & 0.04 \\
\hline Mean gradient $(\mathrm{mmHg})$ & $11.0(8.0-15.0)$ & $11.0(9.0-15.0)$ & $11.0(7.0-16.0)$ & 0.57 \\
\hline Aortic regurgitation degree & & & & 0.85 \\
\hline None (grade 0/4) & $25(34 \%)$ & $11(32 \%)$ & $14(35 \%)$ & \\
\hline Trace (grade $1 / 4$ ) & $39(53 \%)$ & $19(56 \%)$ & $20(50 \%)$ & \\
\hline Mild (grade 2/4) & $10(14 \%)$ & $4(12 \%)$ & $6(15 \%)$ & \\
\hline Hospital length of stay & $6(5-8)$ & $7(5-9)$ & $4(4-7)$ & 0.01 \\
\hline \multicolumn{5}{|l|}{ Follow-up } \\
\hline New onset AF & $6(8 \%)$ & $4(13 \%)$ & $2(5 \%)$ & 0.39 \\
\hline Heart failure hospitalization & $4(5 \%)$ & $3(9 \%)$ & $1(2 \%)$ & 0.31 \\
\hline Sudden death & $0(0 \%)$ & $0(0 \%)$ & $0(0 \%)$ & \\
\hline All-cause mortality & $3(4 \%)$ & $2(6 \%)$ & $1(2 \%)$ & 0.59 \\
\hline \multicolumn{5}{|l|}{ Among No PPM patients } \\
\hline Syncope/faintness & & & $1(2 \%)$ & \\
\hline PPM implantation & & & $2(5 \%)$ & \\
\hline
\end{tabular}

Values are median (interquartile range). $\mathrm{n}(\%)$. or mean \pm standard deviation $\mathrm{AF}=$ atrial fibrillation $; \mathrm{CAVB}=$ complete atrioventricular block $; \mathrm{PPM}=$ Permanent pacemaker.

$\dagger$ All vascular complications were minor. 